\section{Tuberculosis transmission across the United States-Mexico border}

\author{
Joseph Robert Fitchett, \\ Antonio Javier Vallecillo, \\ and Clara Espitia
}

Suggested citation: Fitchett JR, Vallecillo AJ, Espitia C. Tuberculosis transmission across the United States-Mexico border. Rev Panam Salud Publica. 2011;29(1):57-60.

\section{A REMARKABLE SETTING}

The area encompassing the 2000 mile border between the United States (U.S.) and Mexico is of mutual strategic importance to both countries and key to their security and economic prosperity. The U.S.-Mexico border area is also uniquely dynamic. According to the U.S. Department of Transportation and the U.S. Customs Service, nearly 200 million passenger-crossings were made by bus and personal vehicle in 2009 (1). Not only is the volume of documented and undocumented migration high, nonmigrants cross the border on a daily basis for employment, leisure, and to visit family. Furthermore, a significant portion of the U.S. population is of Mexican descent, as underscored by President Felipe Calderon of Mexico who said: "Mexico does not end at its border."

In a world characterized by globalization, policies concerning health security, communicable diseases, and health care are increasingly important. Infectious disease transmission along the U.S.-Mexico border is an area for particular concern. Although tuberculosis (TB) trends in the U.S. and in Mexico are encouraging, with prevalence levels currently at 9500 and 24000 respectively $(2,3)$, the advent of drug resistance and the complexities of border population dynamics may cause a considerable threat to the population on either side.

\section{IMMIGRATION POLICY AND U.S.-MEXICO RELATIONS}

In this era of increasing drug resistance among infectious diseases such as tuberculosis (TB), the complex population dynamics of border areas must be monitored more extensively. TB remains a major public health threat; its antimicrobial treatment is long; and the only vaccine licensed in the world, live-attenuated Mycobacterium bovis Bacille Calmette-Guérin (BCG), exhibits varying efficacy. In addition to epidemiological surveillance, the underlying determinants contributing to the health and wellbeing of populations are of key importance. Although it received heightened attention in the past, tuberculosis transmission in the United States-Mexico border area demands renewed interest. Lessons learned should be applied to similar areas around the globe.

Key words: Mycobacterium tuberculosis; border health; epidemiologic surveillance; Mexico; United States.

\footnotetext{
1 London School of Hygiene and Tropical Medicine, Department of Infectious and Tropical Diseases, London, United Kingdom; and the Imperial College of London, Faculty of Medicine, London, United Kingdom. Send correspondence to: Joseph R. Fitchett, joseph.fitchett@doctors.org.uk and/or joseph.fitchett06@imperial.ac.uk

2 Universidad Nacional Autónoma de México, Departamento de Inmunología, Instituto de Investigaciones Biomédicas, Mexico City, Mexico.
}

Immigration is not new to the United States. On the contrary, over the course of this vast country's history, immigration has traditionally been a crucial source of population growth. In 1790, Congress began a process for enabling foreign-born individuals to become U.S. citizens (4). In 2008, nearly 190000 individuals from Mexico obtained legal permission for permanent residency in the United States, and an additional 231000 were naturalized (5). Non-immigrant admissions to the United States from Mexico reached over 7.2 million in 2008, by far the most from any single country, equivalent to $18.5 \%$ of the total. Mexico is also the source of the highest proportion of temporary and seasonal worker admissions, over 300000 individuals in 2009 (5). Worth noting is that in 2009, according to the U.S. Office of Immigration Statistics, nearly 530000 "deportable aliens" were identified as being Mexican nationals (5). Over 280000 were removed from the United States, 34\% with a criminal conviction. However, these figures are eclipsed by the estimated number of unauthorized immigrants in the United States: in 2009, 62\% of the estimated 10.8 million illegal immigrants in the United States were thought to be from Mexico (6). 
During 1994-2009, commercial ties between the United States and Mexico were cemented, and trade more than quadrupled (7). Indeed, the majority of foreign direct investment in Mexico originates from the United States. In 2008, $10 \%$ of U.S. merchandise imports came from Mexico, and $11 \%$ of U.S. merchandise exports were destined for Mexico; whereas 50\% of Mexico imports originated in the United States, and $82 \%$ of Mexico exports headed to the United States (8). However, Mexico's border states (Baja California, Sonora, Chihuahua, Coahuila, Nuevo León, and Tamaulipas) and U.S. border states (Arizona, California, New Mexico, and Texas) are plagued by Mexico's devastating narcotics war. Violence, drug trafficking, and related security issues are straining relations and diverting limited resources like never before.

\section{TB TRANSMISSION: A PUBLIC HEALTH CONCERN}

TB has various mycobacterial strains, collectively termed the Mycobacterium tuberculosis complex, that cause disease via airborne droplet transmission. Predominantly, but not exclusively affecting the lungs, (9) TB is a leading cause of morbidity and mortality around the globe, with more than 9 million new cases and nearly 2 million deaths in 2007 (10). In terms of clinical manifestations, $\mathrm{TB}$ is commonly associated with cough, fever, night sweats, and weight loss. Diagnosis may take a considerable amount of time and relies on clinical signs, chest $\mathrm{X}$-ray, blood tests for cytokine secretion, and sputum smear microscopy with Ziehl-Neelsen staining.

Since 1980, TB incidence and disease burden have grown steadily worldwide, with latent TB infection rates estimated at one-third of the world's population (11). In 1993, the World Health Organization (WHO) declared TB a global emergency.

Epidemiologically, the population along the U.S.- Mexico border area can be considered one population, with inhabitants crossing routinely and legally for employment and social, touristic, and medical reasons. Research indicates that in 1993-2001, 76.7\% of the 16223 total tuberculosis cases among Mexicanborn patients in the United States were in Arizona, California, New Mexico, and Texas (12). Additionally, co-infection with HIV, drug and alcohol dependency, and criminal records were less likely to be reported in this patient group (12). Underscoring the urgency of tackling TB is the increase in drug resistance in these patients, together with data showing that alcohol abusers, Hispanics, and males generally have the least TB-related knowledge (13).

Furthermore, despite the availability of free TB treatment in the United States and a $96 \%$ coverage rate by Directly Observed Treatment Short-Course (DOTS) in Mexico (10), patients without long-term health care insurance will find the long treatment challenging, perhaps deal with drug resistance, and potentially return to or visit Mexico and transmit TB to their contacts.

\section{EMERGENCE OF MULTIDRUG RESISTANCE}

Active TB infection demands long courses of antimycobacterial drugs: an intensive course of rifampicin, isoniazid, pyrazinamide, and ethambutol for 2 months, followed by a continuation course of rifampicin and isoniazid for 4 months (14). An untreated TB patient may infect 15 people a year, and mortality can be as high as 50\% (15).

Treatment compliance is absolutely essential to ensuring complete elimination of infection and preventing the emergence of multidrug-resistant (MDR) and extensively drug-resistant (XDR) strains. The introduction of DOTS by WHO in 1993 improved compliance, however the emergence of drug resistant strains, the global HIV epidemic, and a lack of resources have complicated efforts to successfully treat TB $(16,17)$.

MDR-TB and XDR-TB have become a public health emergency of growing urgency worldwide. With great variability in clinical outcomes, MDR-TB and XDR-TB threaten to make infection untreatable (18). Emergence of $M$. tuberculosis resistance to antimycobacterial agents is considerable in 5 of the 6 Mexican states that border the United States, and recent data even indicate higher figures than those reported by WHO surveillance (19). In drug-resistant cases, DOTS may compound the clinical course of the patient, leading to treatment failure (20) and longer periods of TB transmissibility (21). Delays in preventative measures, diagnosis, and treatment add to the complexity of the current situation.

Recent WHO estimates indicate that the MDRTB rate is $1.2 \%$ of all TB cases in the United States, and $5.8 \%$ of those in Mexico (22). However, some discrepancies exist between the two countries regarding the diagnosis of drug resistant cases. In the United States, all samples positive for $M$. tuberculosis are subjected to drug resistance testing. In areas of Mexico where drug resistant testing is not routine, a selection bias for TB patients that are tested may impact the accuracy of drug resistance data. In addition, in areas where access to health care is poor, patients suffering from active TB may not receive the treatment they require, again complicating and skewing the accuracy of current estimates.

In 2007, $84.5 \%$ of MDR-TB cases in the United States were among foreign-born persons, with Mexico being the most common country of origin for active TB cases in this group, or about $25 \%$ of all foreign-born cases (23). In California for instance, Mexico is noted as the most common country of origin for patients with MDR-TB (27.8\%) and with XDR-TB (46.7\%) (24).

Drug resistance rates on one side of the border may impact rates on the other side of the border. At present, with no enforceable TB patient tracking system for the 10 states that makeup the border area, efforts must be made to ensure continuity of care between the two countries. The timely establishment of projects, such as the CureTB: Binational TB Referral Program and TBNet, are welcome and timely contri- 
butions to transmission prevention efforts. However, services on both sides of the border need to be better integrated to rectify inadequate continuity of care. Furthermore, the continuous movement across the border may be a force driving the emergence of drug resistant strains. This dynamic deserves further study, with particular emphasis on effective policies for nonmigrants-those working or visiting across the border.

\section{TRANSMISSION PREVENTION STRATEGIES}

An influential study indicates that U.S.-funded efforts to support TB treatment programs in Mexico may be helping to control the disease within Mexico, as well as reducing TB-related morbidity and mortality among migrants to the United States (25). Currently, not all visitors to the U.S., whether from Mexico or countries with even higher TB incidence/ prevalence, are screened for TB. Although TB incidence and prevalence is relatively low in both the United States and Mexico, TB incidence in Mexican migrants to the United States remains steady, with screening for TB in the country of origin and follow-up after arrival in the United States being an efficient transmission prevention method (26).

Key improvements in TB surveillance along the border must include a case definition and registry of cases, a system to find infected patients, increased funding for services, laboratory support (with emphasis on TB testing in migrants), and contact tracing. High-risk populations must be identified and have access to quality, continuous, and consistent health care. In areas and among populations with high migration and drug-resistance, patient followup to ensure treatment completion and novel diagnostics are crucial to lowering TB prevalence rates. Capacity and health systems strengthening are key to tackling conditions, such as TB and other infectious diseases. Moreover, a clear division of labor and coordinated activities are required to adequately identify, monitor, and subsequently, treat TB infections where there is considerable population movement and high numbers of migrants.

\section{HEALTH CARE WORKERS LEAD THE WAY}

With research indicating differences in the clinical presentation of TB among undocumented migrants and documented migrants/U.S.-born individuals, poor surveillance and documentation may be masking a growing problem (27). Despite some focus at the turn of the millennium on TB transmission across the U.S.Mexico border, such as establishment of the 1997 U.S.-Mexico Border Infectious Disease Surveillance (BIDS) project (28) and the 1999 Centers for Disease
Control and Prevention working group (29), activity on the issue seems to have diminished in recent years. BIDS does not collect data for TB disease, and since the dynamics of the border area are so active, more thought is needed to improve policy for health security.

The 7th Annual Forum of the U.S.-Mexico Border Centers of Excellence Consortium in July 2010 sought capacity building and decisive leadership on both sides of the border for long-term prosperity and health in the area. Health care workers must lead the way. Bilateral collaboration in the field of public health research would prove a constructive policy for improving ambiguous relations, communication, and cooperation among Mexico and the United States, benefiting the citizens of both countries.

As epitomized by the recent Swine Influenza H1N1 pandemic, health is undeniably global. With the emergence of MDR-TB and XDR-TB, as well as continued immigration (documented and undocumented), this public health threat is present and needs improved monitoring and investigation. Foreign policy needs to place more emphasis on health in order to meet today's emerging challenges.

Lastly, although the U.S.-Mexico border area is unique, health professionals and policymakers in other countries can apply its lessons learned when considering options for protecting their own citizens and shared borders.

\section{SINOPSIS}

\section{Transmisión transfronteriza de la tuberculosis entre México y los Estados Unidos}

En esta época en la que cada vez es mayor la farmacorresistencia de enfermedades infecciosas como la tuberculosis, es preciso vigilar más ampliamente la compleja dinámica de la población de las zonas fronterizas. La tuberculosis sigue siendo un problema muy importante de salud pública, el tratamiento antimicrobiano es prolongado y la vacuna BCG (Bacilo de Calmette-Guérin) -la única autorizada en el mundo, elaborada con bacilos atenuados de Mycobacterium bovis- tiene eficacia variable. Además de la vigilancia epidemiológica, revisten suma importancia los determinantes fundamentales que inciden en la salud y el bienestar de las poblaciones. Si bien la transmisión transfronteriza de la tuberculosis entre México y los Estados Unidos recibió gran atención en el pasado, la situación actual exige renovar el interés por este tema. Es necesario aplicar las lecciones aprendidas en zonas similares del resto del mundo.

Palabras clave: Mycobacterium tuberculosis; salud fronteriza; vigilancia epidemiológica; Estados Unidos; México. 


\section{REFERENCES}

1. Bureau of Transportation Statistics. Border crossing: US-Mexico border crossing data. Washington DC: US Department of Transportation; 2009. Available from: http://www.transtats.bts.gov/ BorderCrossing.aspx. Accessed 5 May 2010.

2. World Health Organization. USA TB country profile. Geneva: WHO; 2009. Available from: http://apps.who.int/ globalatlas/predefinedreports/tb/PDF Files/usa.pdf. Accessed 5 May 2010.

3. World Health Organization. Mexico TB country profile. Geneva: WHO; 2009. Available from: http://apps.who.int/ globalatlas/predefinedreports/tb/PDF Files/mex.pdf. Accessed 5 May 2010

4. Congressional Budget Office. Immigration policy in the United States. Washington DC: Congress of the United States; 2006.

5. Office of Immigration Statistics. 2009 yearbook of immigration statistics. Washington DC: US Department of Homeland Security; 2010. Available from: http://www.dhs.gov/xlibrary/ assets/statistics/yearbook/2009/ois yb_2009.pdf. Accessed 22 November 2010.

6. Hoefer M, Rytina N, Baker BC. Estimates of the unauthorized immigrant population residing in the United States: January 2009. Washington DC: US Department of Homeland Security, Office of Immigration Statistics; 2009.

7. Sullivan MP, Beittel JS. Mexico-US relations: issues for Congress. Washington DC: Congressional Research Service; 2009.

8. Villareal MA. US-Mexico Relations: Trends, issues and implications. Washington DC: Congressional Research Service; 2009.

9. Kaufmann $\mathrm{SH}$. Recent findings in immunology give tuberculosis vaccines a new boost. Trends Immunol. 2005;26: 660-7.

10. World Health Organization. Global tuberculosis control: epidemiology, strategy, financing. Geneva: WHO; 2009. Available from: http://www.who.int/ tb/publications/global_report/2009/ pdf/full_report.pdf. Accessed 5 May 2010
11. Jasmer RM, Nahid P, Hopewell PC. Clinical practice: latent tuberculosis infection. New Engl J Med. 2002;347: 1860-66.

12. Schneider E, Laserson KF, Wells CD, Moore M. Tuberculosis along the United States-Mexico border, 1993-2001. Pan Am J Public Health. 2004;16(1):23-4.

13. Marks SM, Deluca N, Walton W. Knowledge, attitudes and risk perceptions about tuberculosis: US National Health Interview Survey. Int J Tuberc Lung Dis. 2008;12(11):1161-7.

14. World Health Organization. Treatment of tuberculosis: guidelines. 4th $\mathrm{Ed}$. Geneva: WHO; 2010. Available from: http://whqlibdoc.who.int/publica tions/2010/9789241547833_eng.pdf. Accessed 5 May 2010.

15. Onyebujoh P, Rook GA. Tuberculosis. Nature Rev Microbiol. 2004;2:930-2.

16. World Health Organization. Global map and information on XDR-TB. Geneva: WHO; 2009. Available from: http://www.who.int/tb/publications/ global_report/2009/pdf/full_report. pdf. Accessed 5 May 2010.

17. Kaufmann SHE, Parida SK. Changing funding patterns in tuberculosis. Nat Med. 2007;13:299-303.

18. Chan ED, Iseman MD. Multidrugresistant and extensively drug-resistant tuberculosis: a review. Curr Opin Infect Dis. 2008;21:587-95.

19. Zazueta-Beltran J, León-Sicairos $C$, and Canizalez-Roman A. Drug resistant Mycobacterium tuberculosis in Mexico. J Infect Developing Countries. 2009;3(3): $162-8$.

20. DeRiemer K, Garcia-Garcia L, Bobadilladel-Valle M, Palacios-Martinez M, Martinez Gamboa A, Small PM, et al. Does DOTS work in populations with drug-resistant tuberculosis? Lancet. 2005; 365:1239-45.

21. Garcia-Garcia ML, Ponce-de-Leon A, Jiminez-Corona ME, Jiminez-Corona A, Palacios-Martinez M, BalandranoCampos S, et al. Clinical consequences and transmissibility of drug-resistant tuberculosis in southern Mexico. Arch Intern Med. 2000;160:630-6.

22. World Health Organization. Anti-tuberculosis drug resistance in the world: 4 th
Global Report. Geneva: WHO; 2008. Available from: http:/ / whqlibdoc.who. int/hq/2008/WHO_HTM_TB_2008.394 eng.pdf. Accessed 5 May 2010.

23. United States-Mexico Border Health Commission. Tuberculosis along the United States-Mexico border: a white paper. El Paso: BHC; 2009. Available from: http://pm3.stantonstreetgroup. com/newsletters/us_border_health/ files/newsletters_article7688.pdf. Accessed 5 May 2010.

24. Banerjee R, Allen J, Westenhouse J, Oh P, Elms W, Desmond E, et al. Extensively drug-resistant tuberculosis in California, 1993-2006. Clin Infect Dis. 2008;47:450-7.

25. Schwartzman K, Oxlade O, Barr RG, Grimard F, Acosta I, Baez J, et al. Domestic returns from investment in the control of tuberculosis in other countries. New Engl J Med. 2005;353:1008-20.

26. Liu Y, Weinberg MS, Ortega LS, Painter JA, Maloney SA. Overseas screening for tuberculosis in US-bound immigrants and refugees. New Engl J Med. 2009; 360:2406-15.

27. Achkar JM, Sherpa T, Cohen HW, Holzman RS. Differences in clinical presentation among persons with pulmonary tuberculosis: a comparison of documented and undocumented foreignborn versus US-born persons. Clin Infect Dis. 2008;47:1277-88

28. Weinberg $M$, Waterman $S$, Alvarez Lucas C, Carrion Falcon V, Kuri Morales P, Anaya Lopez L, et al. The US-Mexico Border infectious diseases surveillance project: establishing a binational border surveillance. In: Emerging Infectious Diseases. Atlanta: United States Centers for Disease Control and Prevention; 2003.

29. Lobato M, Cegielski JP. Preventing and controlling tuberculosis along the USMexico border. Atlanta: United States Centers for Disease Control and Prevention; 2001.

Manuscript received on 3 January 2010. Revised version accepted for publication on 17 September 2010. 